\title{
Correction to: EGFR and BRAF mutations in inverted sinonasal papilloma-a more complex landscape?
}

\author{
Sarah Zonnur ${ }^{1} \cdot$ Andreas Erbersdobler $^{1} \cdot$ Björn Schneider $^{1}(\mathbb{C}$
}

Published online: 19 July 2021

(c) The Author(s) 2021

\section{Correction to: Virchows Archiv (2021) 478:915-924}

https://doi.org/10.1007/s00428-020-02945-y

The article "EGFR and BRAF mutations in inverted sinonasal papilloma - a more complex landscape?", written by Sarah Zonnur, Andreas Erbersdobler and Björn Schneider, was originally published Online First without Open Access. After publication in volume 478, issue 5, page 915-924 the author decided to opt for Open Choice and to make the article an Open Access publication. Therefore, the copyright of the article has been changed to (c) The Author(s) 2021 and the article is forthwith distributed under the terms of the Creative Commons Attribution 4.0 International License, which permits use, sharing, adaptation, distribution and reproduction in any medium or format, as long as you give appropriate credit to the original author(s) and the source, provide a link to the Creative Commons licence, and indicate if changes were made. The images or other third party material in this article are included in the article's Creative Commons licence, unless indicated otherwise in a credit line to the material. If material is not included in the article's Creative Commons licence and your intended use is not permitted by statutory regulation or exceeds the permitted use, you will need to obtain permission directly from the copyright holder. To view a copy of this licence, visit http:// creativecommons.org/licenses/by/4.0.

Publisher's note Springer Nature remains neutral with regard to jurisdictional claims in published maps and institutional affiliations.

The original article can be found online at https://doi.org/10.1007/ s00428-020-02945-y.

Björn Schneider

bjoern.schneider@med.uni-rostock.de

1 Institute of Pathology, University Medicine Rostock,

Strempelstr. 14, 18057 Rostock, Germany 